\title{
Multivariate analysis of risk factors for postpartum depression
}

\section{Analiza wielowymiarowa czynników ryzyka depresji poporodowej}

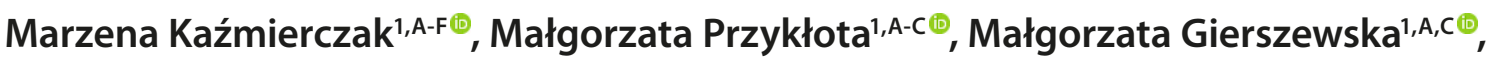

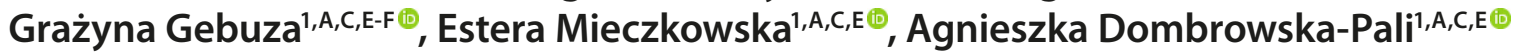 \\ ${ }^{1}$ Nicolaus Copernicus University in Toruń, Faculty of Health Sciences, Collegium Medicum, Bydgoszcz, Poland \\ A - Research concept and design, B - Collection and/or assembly of data, C - Data analysis and interpretation, \\ $D$ - Writing the article, E - Critical revision of the article, F - Final approval of artic
}

\begin{abstract}
Kaźmierczak M, Przykłota M, Gierszewska M, Gebuza E, Dombrowska-Pali A. Multivariate analysis of risk factors for postpartum depression.
\end{abstract} Med Og Nauk Zdr. 2020; 26(2): 139-145. 10.26444/monz/119416

\begin{abstract}
Introduction and objective. Postpartum depression affects between $7 \%-20 \%$ of women worldwide. Risk assessment of depressive symptoms plays a key role in ensuring the mental health and proper functioning of women after childbirth. The aim of the study is to assess the severity of postpartum depression and conduct multivariate analysis of risk factors.

Materials and method. 80 women in the third trimester of pregnancy were invited to participate in the study and asked for contact after childbirth. Recruitment for the study took place while the pregnant women were staying at the Pregnancy Pathology Ward and the Obstetrics and Gynaecology Clinic, Diabetology Clinic and Obstetrics Emergency Room. The research project was carried out from February - May 2019. Ultimately, 70 women took part in the project on average in week 4 of puerperium. The research tools were a questionnaire of own design and the Edinburgh Postnatal Depression Scale. Results. The risk of depressive symptoms was found in $18.6 \%$ of women after childbirth. Multi-dimensional logistic regression showed that age $(p=0.014)$, anxiety due to motherhood $(p=0.019)$ and the occurrence of difficulties in looking after a child ( $p=0.005$ ) were the factors significantly associated with the symptoms of postpartum depression.

Conclusions. The incidence of postpartum depression in the study sample did not differ significantly from the incidence reported in the literature. Worldwide. The risk of postpartum depression symptoms increased with age. Anxiety due to motherhood and difficulties in looking after a child proved to be crucial determinants of depressive symptoms. Fertility at the level of three or more deliveries and individual personality types of women did not influence the occurrence of postpartum depression.
\end{abstract}

\section{Key words}

childbirth, postpartum depression, risk factors, Edinburgh Postnatal Depression Scale

\section{Streszczenie}

Wstęp. Depresja poporodowa dotyczy od 7 do 20\% kobiet na całym świecie. Ocena ryzyka objawów depresyjnych odgrywa kluczową rolę w zapewnieniu zdrowia psychicznego i prawidłowego funkcjonowania kobiet po porodzie.

Cel pracy. Ocena nasilenia depresji poporodowej oraz analiza wielowymiarowa czynników ryzyka.

Materiał i metody. Do badania zaproszono 80 kobiet w III trymestrze ciąży, które poproszono o kontakt po porodzie. Rekrutacja do badania odbywała się w czasie pobytu kobiet ciężarnych na oddziale patologii ciąży i poradniach: położniczo-ginekologicznej, diabetologicznej oraz w położniczej izbie przyjęć. Projekt badawczy przeprowadzono od lutego do maja 2019 roku. Ostatecznie wzięło w nim udział 70 kobiet będących średnio w 4. tygodniu połogu. Narzędzia badawcze stanowiły: kwestionariusz ankiety własnego autorstwa oraz Edynburska Skala Depresji Poporodowej.

Wyniki. Ryzyko objawów depresyjnych stwierdzono u 18,6\% kobiet po porodzie. W wielowymiarowej regresji logistycznej wykazano, że wiek ( $p=0,014)$, niepokój z powodu macierzyństwa $(p=0,019)$ oraz występowanie trudności w opiece nad dzieckiem $(p=0,005)$ były czynnikami istotnie powiązanymi z objawami depresji poporodowej.

Wnioski: Częstość występowania zaburzeń depresyjnych po porodzie w badanej próbie nie różniła się znacząco od częstości podawanej w literaturze światowej. Wraz z wiekiem kobiet wzrastało ryzyko objawów depresji poporodowej. Istotnymi wyznacznikami objawów depresyjnych okazały się zmienne: niepokój z powodu macierzyństwa oraz trudności w opiece nad dzieckiem. Rodność na poziomie 3 lub więcej porodów i poszczególne typy osobowości kobiet nie warunkowały występowania depresji poporodowej.

\section{Słowa kluczowe}

poród, depresja poporodowa, czynniki ryzyka, Edynburska Skala Depresji Poporodowej

\footnotetext{
Address for correspondence: Marzena Kaźmierczak, Nicolaus Copernicus University in Toruñ, Faculty of Health Sciences, Collegium Medicum in Bydgoszcz, ul. Łukasiewicza 1, 85-821 Bydgoszcz, Poland E-mail: marzena.kazmierczak@cm.umk.pl

Received: 21.01.2020; accepted: 22.03.2020; first published: 25.04.2020
}

\section{INTRODUCTION}

Postpartum depression is a serious disorder diagnosed as an episode of major depression occurring within four weeks after childbirth, 'with perinatal onset' according to DSM-5, which also allows inclusion of the period of pregnancy [1, 2]. In Poland, routine screening for postnatal depression has 
currently not been common. At present, in accordance with the Regulation of the Minister of Health on the organizational standard of perinatal care, the triple screening test has been recommended since 1 January 2019, in order to assess the risk and severity of depression symptoms in women in the perinatal period [3]. Implementation of common screening tests using available and reliable tools is a priority for perinatal care, and thus will enable quick intervention when risk factors for psychiatric disorders are found in women in the perinatal period.

Globally, postpartum depression concerns from 7\% - 20\% of women at childbearing age $[4,5]$. The aetiology of postpartum depression has a complex pathophysiology and probably results from the interaction of genetic, neuroendocrine and psychosocial factors. The significant factors which predispose to the development of the disease include: young age of women, low level of education, loneliness of the mothers, lack of social support, or experiencing stressful events during pregnancy [6]. The exposure of women to domestic violence in the perinatal period increases the likelihood of postpartum depression more than threefold. The risk of depression is most often found in the youngest women (18-24 years), without previous depressive symptoms, but who have experienced physical violence [7]. Negative childhood experiences and domestic violence during a woman $>$ s pregnancy are global mental health problems in the perinatal period [8]. Women who give their babies formula milk are more susceptible to postpartum depression than women who breastfeed [9]. Family history of depression, personal history of depressive episodes, or the sense of unhappiness due to unplanned pregnancy, are important predictors of postpartum depression [10]. Early anaemia in women after delivery is a significant risk factor for depressive symptoms $[11,12]$. Significant relationships between premenstrual syndrome, stress connected with looking after a child and pain during the puerperium and depressive symptoms in women after childbirth, have been identified. [13]. A multicentre retrospective study among a representative sample of women $(n=4,410)$ reports that significant risk factors for depression after childbirth include a severe form of premenstrual syndrome, high levels of neuroticism, multiparity, stressful life events, lack of social support, and childhood sexual abuse [14].

Although risk factors for postnatal depression reported in the scientific literature are numerous and complicated, they are seldom clearly defined. The results of the current study should provide valuable tips for medical staff who look after women and their children after childbirth in order to eliminate potential risk factors that cause the development of postpartum depression. Every effort should be made to implement the available procedures for risk assessment, diagnosis, psychotherapy and pharmacotherapy.

\section{OBJECTIVE}

The aim of the study is to assess the severity of postpartum depression and conduct multivariate analysis of risk factors.

\section{MATERIALS AND METHOD}

The study was approved by the Management of the University Hospital No. 2 in Bydgoszcz and Bioethics Committee of the
Nicolaus Copernicus University in Toruń (No. 830/2019), Poland. 80 women in the third trimester of pregnancy were invited to participate in the the study and asked for contact after childbirth. Recruitment for the study took place while the pregnant women were staying at the Pregnancy Pathology Ward and the Obstetrics and Gynaecology Clinic, Diabetology Clinic and Obstetrics Emergency Room. The study was conducted from February - May 2019. Selection of the respondents was intentional. The women gave their written consent to participate in the project and the will to complete the questionnaires by phone or e-mail with the authors of the study. As a result, 70 women in the 4 th week after childbirth, on average (min. 3 weeks, max. 6 weeks after delivery), responded to the invitation. The women were instructed in how to complete the self-assessment questionnaires, and on the possibility of resigning from participation at any time during the study.

The average age of the women was 31.27 years $(\mathrm{SD}=5.19)$. The average week of pregnancy completion was 39 weeks $(\mathrm{SD}=1.49)$. Detailed socio-demographic and clinical characteristics of the studied sample are shown in Table 1 . The accompanying person was usually the husband (64.3\%), partner (18.6\%), sister (1.4\%), or a friend (1.4\%). $14.3 \%$ of the women gave birth without a close person being present. $30 \%$ of the respondents reported negative life events during the last six months. Mental problems before pregnancy appeared in $7.1 \%$ of the respondents, and $5.7 \%$ of the women declared that they had been treated at the Mental Health Clinic. $17.2 \%$ of the women confirmed they had previously had help from a psychologist, and only one respondent had consulted a psychiatrist during pregnancy. 3.5\% of the women reported subjective mood disorders in the current pregnancy. The occurrence of mental disorders in the family was reported by $24.3 \%$ of the respondents, and $12.9 \%$ indicated suicide attempts or suicide in the family. $12.9 \%$ of the women had experienced a depressed mood in the previous pregnancy, whereas postpartum depression was reported by only one patient.

After childbirth, the women most often received social (emotional and instrumental) support from husbands and partners. Anxiety associated with motherhood was declared by $44.3 \%$ of the women, and $21.4 \%$ thought that they would not manage to look after their child. The women considered their labour to be stressful (31.4\%), hard (21.2\%), painful $(11.4 \%)$, very long $(11.4 \%)$, a great experience $(10 \%)$, quick $(7,2 \%)$, and traumatic (7.1\%). The women most often defined their personality traits as: optimistic $(65.8 \%)$, perfectionist (15.7\%), introverted (5.7\%) pessimistic (5.7\%), realistic (5.7\%) and neurotic (1.4\%).

Measurements. The research method was a diagnostic survey with the following research tools: the Edinburgh Postnatal Depression Scale and the author's questionnaire. The questionnaire for pregnant women developed for the purpose of the study was used to collect socio-demographic and clinical data. The personal questionnaire for women after childbirth was used to collect information on the course of pregnancy, delivery and puerperium, received social support, depressed mood in previous pregnancies and after childbirth, the occurrence of mental disorders in the family, and personality traits.

The Edinburgh Postpartum Depression Scale by J.L. Cox, R.M. Holden and R. Sagovsky, which is characterized by 
Table 1. Characteristics of the study sample

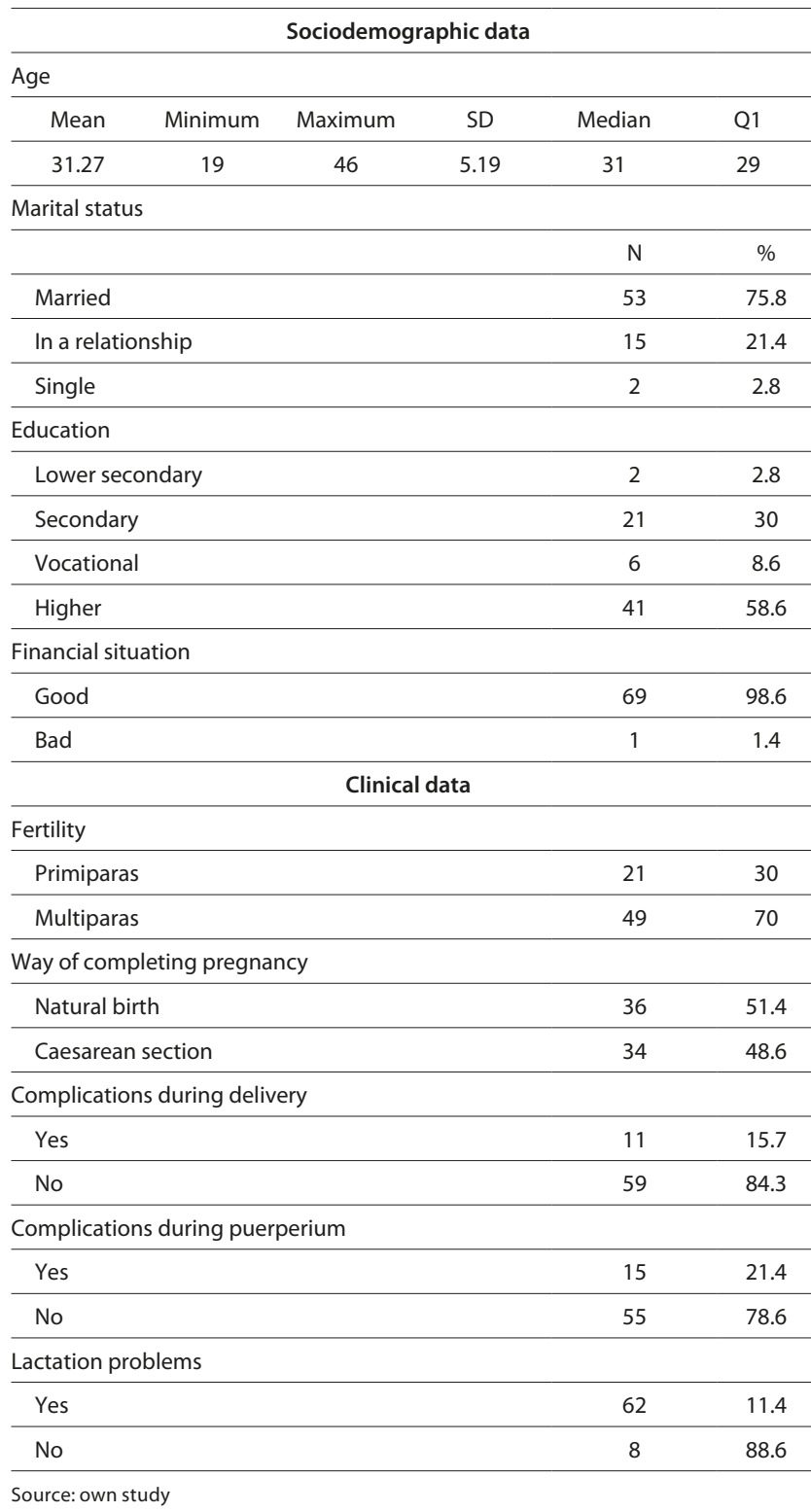

high sensitivity and specificity, was used to assess the risk of worsening depressive symptoms in women in the postpartum period. The tool has good psychometric properties [15]. In the research carried out by Kaźmierczak et al. [16], the Cronbach's alpha reliability coefficient for the EPDS scale was estimated at 0.87 , and the reliability of the tool for the studied sample was confirmed. In the original studies, sensitivity was $86 \%$, specificity $78 \%$, and the Cronbach alpha reliability coefficient -0.88 . The scale consists of 10 statements related to various aspects of mental state, e.g. anhedonia (1 and 2), the feeling of guilt (3), anxiety (4), occurrence of panic attacks (5), fatigue (6), sleep disorders (7), feeling of loneliness (8), fretfulness (9), and the occurrence of suicidal thoughts (10) [15]. The authors of the current study determined that the risk of depressive symptoms in women after delivery will be the value of EPDS 12 points. Respondents who were at risk (score 12 points on the EPDS scale, or those who scored 10 points) were informed about the necessity to see a psychologist or a psychiatrist.
Analysis of the collected material was performed by statistical package $\mathrm{R}$, version 3.5.4. Normality of the distribution in the subgroups was checked by means of the Shapiro-Wilk test, and there was no normal distribution of quantitative variables. Nominal data was compared between groups by the chi-square test. Due to the lack of normal distribution for quantitative variables (age, level of depression), comparisons between individual subgroups were made with the non-parametric Mann-Whitney U test, Wilcoxon signed-rank test or Kruskal-Wallis test. Spearman's correlation coefficient was used to compare age in relation to the level of depression. All tests were two-tailed, with a significance level of 0.05 . In order to identify the combinations of variables which significantly influence the onset of postpartum depression, an additional analysis was conducted which involved building a multidimensional logistic regression model. The model used variables for which comparative analysis of the groups showed that they significantly differentiate the level of depression. The quality of the logistic regression model was assessed by means of the Hosmer-Leweshow test.

\section{RESULTS}

$18.6 \%$ of women after childbirth obtained the score of 12 points on the EPDS scale. Descriptive statistics of the scale have been included in Table 2. In order to determine whether there are factors that differentiate the risk of postpartum depression, it was decided to choose obstetric, psychosocial and age variables. As a result, the statistical analysis showed a significant difference between the age of the women and the risk of worsening depressive symptoms ( $r s=0.38 ; \mathrm{p}=0.001$ ). The correlation was positive with moderate strength. This means that as the age of respondents increases, the level of postpartum depression also increases; however, this relationship is of moderate strength. The women's multiparity differentiated the level of depressive disorders $(p=0.049)$. There are no grounds for the remaining obstetric variables to state that they differentiate mental disorders after childbirth ( $>0.05)$. Data from the observations is shown in Table 3. It was confirmed that the women who felt anxiety due to motherhood presented significantly higher levels of postpartum depression disorders than the mothers who did not experience this condition ( $p=0.023)$. Difficulties in looking after a child significantly increased depressive symptoms among the respondents $(\mathrm{p}=0.009)$. Women's personality type significantly differentiated the PPD level. Women with a pessimistic personality showed a significantly higher level of postpartum depression than all other personality types $(\mathrm{p}=0.037)$. The relationship between other psychosocial variables that were taken into account and the risk of depression after childbirth could not be confirmed (Tab. 4).

After identifying the group of variables which significantly differentiated the level of depressive disorders after

Table 2. Descriptive statistics of the EPDS scale

\begin{tabular}{lccccccccc}
\hline EPDS & $\mathrm{N}$ & $\%$ & Mean & $\begin{array}{c}\text { Mini- } \\
\text { mum }\end{array}$ & $\begin{array}{c}\text { Maxi- } \\
\text { mum }\end{array}$ & SD & Median & Q1 & Q3 \\
\hline $0-11$ & 57 & 81.4 & 4.35 & 0 & 11 & 3.16 & 3 & 2 & 6 \\
\hline $12-30$ & 13 & 18.6 & 12.77 & 12 & 14 & 0.83 & 13 & 12 & 13 \\
\hline Total & 70 & 100 & 8.56 & 0 & 14 & 1.99 & 8 & 7 & 9.5 \\
\hline
\end{tabular}

Source: own study 
Table 3. Determining the difference between EPDS and obstetric variables

\begin{tabular}{|c|c|c|c|c|}
\hline Variable & $N$ & $\begin{array}{l}\text { The level of depression } \\
\text { after childbirth } \\
\text { according to the EPDS scale }\end{array}$ & $\begin{array}{c}\text { Test } \\
\text { statistic }\end{array}$ & $P$ \\
\hline \multicolumn{5}{|l|}{ Fertility } \\
\hline First childbirth & 23 & $4.0(2.0-10.0)$ & \multirow{3}{*}{$\begin{array}{c}x^{2}=6.037 \\
d f=2\end{array}$} & \multirow{3}{*}{0.049} \\
\hline Second childbirth & 27 & $3.0(1.5-8.5)$ & & \\
\hline Third and next childbirth & 20 & $7.5(4.0-11.3)$ & & \\
\hline \multicolumn{5}{|c|}{ Way of completing pregnancy } \\
\hline Natural birth & 36 & $4.0(2.8-9.0)$ & \multirow{2}{*}{$W=529.50$} & \multirow{2}{*}{0.33} \\
\hline Caesarean section & 34 & $4.0(2.0-12.0)$ & & \\
\hline \multicolumn{5}{|l|}{ Complications during delivery } \\
\hline Yes & 11 & $7.0(2.0-10.0)$ & \multirow{2}{*}{$W=338.50$} & \multirow{2}{*}{0.827} \\
\hline No & 59 & $4.0(2.5-10.0)$ & & \\
\hline \multicolumn{5}{|c|}{ Complications during puerperium } \\
\hline Yes & 15 & $4.0(2.0-10.5)$ & \multirow{2}{*}{$W=388.50$} & \multirow{2}{*}{0.735} \\
\hline No & 55 & $4.0(2.5-10.0)$ & & \\
\hline \multicolumn{5}{|l|}{ Lactation problems } \\
\hline Yes & 62 & $4.0(3.0-10.8)$ & \multirow{2}{*}{$W=189.50$} & \multirow{2}{*}{0.282} \\
\hline No & 8 & $2.5(2.0-5.0)$ & & \\
\hline
\end{tabular}

Source: own study

Table 4. Determining the difference between EPDS and psychosocial variables

\begin{tabular}{|c|c|c|c|c|}
\hline Variable & $N$ & $\begin{array}{l}\text { The level of depression } \\
\text { after childbirth } \\
\text { according to the EPDS scale }\end{array}$ & $\begin{array}{c}\text { Test } \\
\text { statistic }\end{array}$ & $P$ \\
\hline \multicolumn{5}{|c|}{ Negative life events over the past 6 months } \\
\hline Yes & 21 & $9.0(2.0-11.0)$ & \multirow{2}{*}{$W=560.50$} & \multirow{2}{*}{0.558} \\
\hline No & 49 & $4.0(3.0-8.0)$ & & \\
\hline \multicolumn{5}{|c|}{ Mental disorders in family } \\
\hline Yes & 17 & $4.0(2.0-10.0)$ & \multirow{2}{*}{$W=451.00$} & \multirow{2}{*}{$>0.999$} \\
\hline No & 53 & $4.0(3.0-10.0)$ & & \\
\hline \multicolumn{5}{|c|}{ Anxiety due to motherhood } \\
\hline Yes & 31 & $8.0(3.0-12.0)$ & \multirow{2}{*}{$W=796.00$} & \multirow{2}{*}{0.023} \\
\hline No & 39 & $3.0(2.0-6.0)$ & & \\
\hline \multicolumn{5}{|c|}{ Midwife's support during childbirth } \\
\hline Yes & 42 & $4.0(2.0-9.0)$ & \multirow{2}{*}{$W=467.50$} & \multirow{2}{*}{0.148} \\
\hline No & 28 & $6.0(2.8-12.0)$ & & \\
\hline
\end{tabular}

Support from a close person during childbirth

\begin{tabular}{|c|c|c|c|c|}
\hline From a husband & 45 & $4.0(3.0-9.0)$ & \multirow{4}{*}{$\begin{array}{c}x^{2}=1.32 \\
d f=3\end{array}$} & \multirow{4}{*}{0.724} \\
\hline From a partner & 13 & $4.0(2.0-12.0)$ & & \\
\hline From other close people & 2 & $2.5(2.3-2.8)$ & & \\
\hline I gave birth alone & 10 & $3.5(3.0-11.8)$ & & \\
\hline \multicolumn{5}{|c|}{ Difficulties in looking after a child } \\
\hline Yes & 10 & $11.0(8.3-12.8)$ & \multirow{2}{*}{$W=455.00$} & \multirow{2}{*}{0.009} \\
\hline No & 60 & $4.0(2.0-9.0)$ & & \\
\hline \multicolumn{5}{|l|}{ Type of personality } \\
\hline Optimistic & 46 & $4.0(2.3-9.8)$ & \multirow{5}{*}{$\begin{array}{c}x^{2}=10.24 \\
d f=4\end{array}$} & \multirow{5}{*}{0.037} \\
\hline Pessimistic & 4 & $12.5(11.3-13.3)$ & & \\
\hline Introverted & 4 & $2.5(1.0-4.3)$ & & \\
\hline Perfectionist & 11 & $5.0(3.0-12.0)$ & & \\
\hline Other & 5 & $3.0(2.0-4.0)$ & & \\
\hline
\end{tabular}

Source: own study childbirth, a logistic regression analysis was conducted in order to determine the combination of variables significantly predicting the risk of postpartum depression The model demonstrated that the risk of depression after childbirth was significantly influenced by the following variables: age $(p=0.014)$, occurrence of anxiety due to motherhood $(\mathrm{p}=0.019)$, and the occurrence of difficulties in looking after a child $(\mathrm{p}=0.005)$. Multiparity at the level of three or more deliveries, as well as individual personality types, did not prove to significantly influence the risk of postpartum depression. Model verification by means of the Hosmer-Lemeshow test also indicated a good fit of the model, $\chi 2(8)=10.71 ; p=0.219$. Nevertheless, it should be noted that the groups of women with postnatal depression and without depression differ in numbers (13 and 57 women, respectively). Logistic regression analysis, in turn, is sensitive to the situations in which modelled groups show significant differences in numbers. Therefore, the results obtained in the logistic regression analysis should be interpreted with great caution (Tab. 5).

Table 5. Risk factors for postpartum depression - logistic regression model

\begin{tabular}{|c|c|c|c|c|c|}
\hline Variable & $\begin{array}{l}\beta \text { parameter } \\
\text { estimation }\end{array}$ & $\begin{array}{l}\text { Standard } \\
\text { error }\end{array}$ & $P$ & $\begin{array}{l}\text { Odds } \\
\text { ratio } \\
(O R)\end{array}$ & $\begin{array}{c}95 \% \text { of } \\
\text { confidence } \\
\text { level for } O R\end{array}$ \\
\hline Age (years) & 0.37 & 0.15 & 0.014 & 1.44 & $1.14-2.12$ \\
\hline Fertility. 2 childbirths & -3.80 & 1.63 & 0.020 & 0.02 & $0.0004-0.35$ \\
\hline $\begin{array}{l}\text { Fertility. } 3 \text { and more } \\
\text { childbirths }\end{array}$ & -1.74 & 1.61 & 0.279 & - & - \\
\hline $\begin{array}{l}\text { Anxiety due to } \\
\text { motherhood }\end{array}$ & 3.66 & 1.56 & 0.019 & 38.9 & $3.14-2166.14$ \\
\hline $\begin{array}{l}\text { Difficulties in looking } \\
\text { after a child }\end{array}$ & 4.49 & 1.59 & 0.005 & 89.24 & $6.06-4400.73$ \\
\hline $\begin{array}{l}\text { Personality type. } \\
\text { pessimistic }\end{array}$ & 1.83 & 1.79 & 0.306 & - & - \\
\hline $\begin{array}{l}\text { Personality type. } \\
\text { introverted }\end{array}$ & -17.44 & 4064.61 & 0.997 & - & - \\
\hline $\begin{array}{l}\text { Personality type. } \\
\text { perfectionist }\end{array}$ & 1.87 & 1.41 & 0.184 & - & - \\
\hline Personality type. other & -20.32 & 3687.52 & 0.996 & - & - \\
\hline Constant & -15.18 & 5.47 & 0.006 & & \\
\hline
\end{tabular}

Note. $p$ - significance level. $O R$-odds ratio

Source: own study

\section{DISCUSSION}

The mental health problems of mothers are a major problem and a challenge for public health and societies worldwide. Postpartum depression (PPD) is the most common mental illness after childbirth and it can impair the mother's behaviour, and adversely affect the child's cognitive, emotional and behavioural development.

In this study the risk of postpartum depression was assessed in $18.6 \%$ of women at the 4 th week postpartum, on average. The results of the study did not differ significantly from the incidence of PPD in other countries. Hahn-Holbrook et al. [17] performed 291 studies on postpartum depression in which 296,284 women from 56 countries were assessed for PPD risk. Analysis inclusion criterion was postpartum depression up to one year after childbirth. In the largest meta-analysis conducted to-date, global PPD prevalence was $17.7 \%$. 
Differences in the incidence of postpartum depression between countries have been demonstrated, with the highest PPD rates recorded in Chile (38\%) and South Africa (37\%); the lowest were found in Switzerland (11\%), The Netherlands (8\%), Nepal (7\%) and Singapore (3\%). The vast majority (73\%) of international differences in the prevalence of postpartum depression were caused by economic and health factors. Indian women experience depressive symptoms after childbirth at a frequency of $22 \%$ [18]. Similar to the rest of the world, PPD is also a problem in Turkey (23.8\%). In developed cities, $21.2 \%$ of women suffer from postnatal depression, and in developing cities, $25 \%$ of female respondents [19]. A Polish study reports that the risk of PPD in women six weeks after childbirth was $14.2 \%$ [20]. Maliszewska et al. [2] report that $6.4 \%$ of mothers experienced depressive symptoms during the first three months after childbirth. A significant difference in the prevalence of postpartum depression risk was reported in Brazilian women (29.1\%) [21]. Women who became pregnant via Assisted Reproductive Technology (ART) experienced depressive symptoms after childbirth at the frequency of 20.4\%. Amirchaghmaghi et al. [22] did not show a significant difference in the prevalence of PPD in women in their control group (26\%) and in women in the ART group.

Postpartum depression is a clinical disorder which lasts for at least 14 days, causes serious impairment in the functioning of woman, and usually involves professional help. Early detection of risk factors is a crucial step in solving mental health problems among women in the postpartum period. The perinatal period favours routine contacts with healthcare professionals, especially midwives. Knowledge and identification of risk factors will allow the early implementation of preventive or therapeutic interventions when non-pharmacological interventions, including social support, are more important.

The results of the current study have identified only some clinical and psychosocial risk factors for postpartum depression, which are important especially during proper screening for this disease. Postpartum depression may be experienced by woman for the first time (de novo), or she can suffer from depressive symptoms during a current pregnancy, past pregnancies, or past postpartum periods. Postpartum depression can also appear in the context of a family history.

Numerous clinical aspects related to the occurrence of PPD in women have been found in the scientific literature (complicated and prolonged labour, obstetric interventions during labour, pain, postpartum complications) [23]. This study confirmed the relationship between women's multiparity and the severity of depressive symptoms. Women after three or more deliveries presented a significantly higher level of postpartum depression than those who gave birth for the first or second time. The results of the studies carried out by other authors report that the first childbirth significantly correlates with the occurrence of postpartum depression $[24,25]$. Smorti et al. [26] report that women who underwent labour induction had higher PPD levels than women who had spontaneous labour. Women who gave birth by Caesarean section more often suffered from postpartum depression than those who gave birth naturally. Results of the current study do not show a relationship between the risk of worsening PPD and the way of ending pregnancy, nor does it show a relationship between the risk of worsening PPD and the way of completing pregnancy. Sylvén et al. [27] report that Caesarean section and induced labour did not cause a higher level of postpartum depression six weeks after delivery.

The authors of the presented study did not show grounds to state that the following obstetric variables: complications during labour (e.g. lack of labour progress, decelerations in the NST record), postpartum complications (e.g. surgical wound infection, cystitis) or problems with lactation (e.g. oversupply of breastmilk, lack of milk, cracked nipples), differentiated mental disorders after childbirth. Mbarak et al. [6], while analysing the relationship between obstetric factors and the occurrence of PPD, discovered that one out of five women with a history of preeclampsia or eclampsia experienced an increase in the symptoms of postpartum depression. Problems with breastfeeding are considered to be a strong risk factor for developing PPD. In the study by Chiu et al., higher EPDS scores were significantly associated with lower breast-feeding rates. [28]. The current study has shown that the level of postpartum depression increases with the age of the respondents (odds ratio: 1.44; OR 1.14-2.12). Mbarak et al. [6] report that young ( $<20$ years) and single women more often suffered from postpartum depression. Age $\geq 35$ years (odds ratio: 1.821, CI: 1.057-3.137) predisposed to PPD, according to Chiu et al. [28].

Many empirical studies have proven beyond doubt that psychosocial risk factors have a crucial role in causing and maintaining mental disorders in women after childbirth. Psychosocial determinants were most often related to stressors, such as experiencing negative life events, including job loss, parental stress associated with looking after a child with a difficult temperament, colic or excessive crying. The second group of psychosocial risk factors was associated with interpersonal relationships (quality of relations with a partner, mother, mother-in-law, both protective and risk-generating, relationship status, domestic violence). Optimism and social support, as moderators of the effects of stress exposure on mental health after childbirth, have been recently taken into account by researchers [29]. The current study hasconfirmed the relationship between the difficulties in looking after a child and the risk of PPD. Sylvén et al. [27] report that problems with looking after a child intensify depressive symptoms in mothers. In spite of the fact that the appearance of a new baby is often a happy experience, the postpartum period might be also associated with increased psychosocial stress and changes in health behaviours, such as sleep deprivation or insufficient physical activity. As a transformative experience, becoming a parent is followed by hormonal changes and neuroplasticity, changes in self-concept, social roles, and everyday activities [30]. It should be assumed that in some women the image of happy motherhood differs significantly from reality. A newborn baby takes up most of the mother's time, therefore the woman does not have time for herself, her husband / partner or friends. Childbirth does not only involve biological but also social changes. Cultural patterns of motherhood and sexuality can have a significant relationship with restoring physiological functions. In Polish culture, the mother figure is idealized ('Polish mother'), and this image does not match weakness or mood swings [31]. The symptoms of depressive disorders intensification may develop in the context of numerous changes connected with the transition to motherhood and contribute to the feeling of frustration and loss. The presented study confirms a significant relationship between the mother's anxiety due to motherhood and the risk of PPD. Coates et al. [32] report that 'The shock of the new' describes the mothers' difficulties in adapting to the 
demands that the new situation imposes, and the mothers pointed out the significance of social support in 'Meeting new support needs'. The authors conducted a qualitative study among 17 mothers with psychological problems in the first year after giving birth. According to the mothers, their new life after childbirth was different from what they had expected. The fact that they had to become a responsible adult who had to care for their child made them feel overwhelmed. They considered their new baby to be a stranger who demanded so much from them. This feeling of being overwhelmed and unsure frequently resulted from the lack of experience.

Scientific literature reports that mother's earlier mental state of health is a strong indicator of postpartum depression. The occurrence of depression in pregnancy and stressful life events, low self-esteem, and a low level of perceived social support result in an increased risk of postpartum depression. Many studies have confirmed the relationship between postpartum depression and pessimistic personality, low self-esteem, or high levels of women's neuroticism [31, 33].

The results of the current study show that women with a pessimistic personality obtained higher rates on the EPDS scale than perfectionists or optimists. Women with an introverted personality obtained the lowest mean score. In the study carried out by Maliszewska et al., the high level of extraversion of women was a protective factor for the occurrence of depressive disorders after childbirth [34]. Particular attention should be paid to the women who have experienced depression or anxiety disorders before or during pregnancy, and who have a history of mental illness in a close family. The study by Maliszewska et al. [33] confirmed that a positive family history of any mental disorders increases the risk of depressive symptoms in women after childbirth. This hypothesis has not been confirmed by the current study.

Numerous studies have found that the received social support is an important prognostic factor for the development of PPD, and may be a protective factor. A supportive husband and a marital relationship with no tension contributed to a strong social support system for the mother. Strengthening family ties and support received from medical staff are important elements in the prevention of postpartum depression. In a study carried out by Coates et al. [32], women did not receive help with breastfeeding from healthcare professionals and were willing to receive support. In the presented study, the support received from relatives and midwives during childbirth was not an indicator of postpartum depression in women. Other studies report that the likelihood of PPD has increased more than seven-fold if there was conflict with a partner, including serious economic problems and ending the relationship [4,35]. Ongeri et al. [35] report that mothers who had a good relationship with their mother-in-law and partner who assisted in raising the child, were less likely to have PPD. Scientific literature provides significant relationships between prenatal stressful life events and the risk of postpartum depression in women. Different types of life events, depending on the severity of the event (e.g. natural disasters, loss of property, loss of income, death of a loved one, witnessing a crime) can have a differentiated impact on the onset of PPD [29]. However, the current study did not show a relationship between stressful life events which had occurred over the previous six months and the risk of postpartum depression. Heim et al. [36] demonstrated that stress and trauma adversely influenced HPA (hypothalamic-pituitary-adrenal) axis function in mothers, especially
ACTH (corticotropin) and cortisol responses. Another factor which had an impact on dysregulation of the HPA axis in women with postpartum depression was the occurrence of adverse life events, especially early life experiences, for instance, sexual or physical trauma and poverty.

The logistic regression model in the current the study indicates that a rise in the age of mothers by one year increased the risk of postpartum depression by $44 \%$. The occurrence of anxiety associated with motherhood and difficulties in looking after a child also increased the risk of depression (39 and 89 times, respectively). On the other hand, the fact of having a child for the second time reduced the risk of depression by $98 \%$, compared with primiparous women.

The obtained results enable the association of psychosocial factors with maternal stress, which can be quickly identified in screening tests carried out during pregnancy and after childbirth, and which will enable early intervention in the case of women who need professional help. Undertaking psychological interventions, including: reliable antenatal education, home visits by midwives, providing social (emotional, instrumental) support by both relatives and medical staff, strengthening family ties or participation in interpersonal psychotherapy, will significantly reduce the incidence of postpartum depression in women after childbirth. Psychological help is also a kind and supportive attitude towards women in the perinatal period, helping them adapt to the new situation. Such help should be provided by doctors, midwives, nurses, family and, friends, as well as local communities, through formal and informal support groups not connected with the medical community. PPD prevention seems feasible and effective. Since 1 January 2019, Poland has finally been required to introduce screening tests into routine obstetric practice to assess the mental health of future mothers

\section{CONCLUSION}

The risk of postpartum depression was found in $18.6 \%$ of women, on average, four weeks after childbirth. On the basis of the logistic regression model, it was determined that the age of women, anxiety due to motherhood, and difficulties in looking after a child, determined the occurrence of postpartum depression.

\section{REFERENCES}

1.Łojko D, Suwalska A, Rybakowski J. Bipolar and related disorders and depressive disorders in DSM-5. Psychiatr. Pol. 2014; 48(2): 245-260.

2. Maliszewska K, Świątkowska-Freund M, Bidzan M, Preis K. Screening for maternal postpartum depression and associations with personality traits and social support. A Polish follow-up study 4 weeks and 3 months after delivery. Psychiatr Pol.2017; 51(5): 889-898.

3. The Regulation of the Minister of Health on the organizational standard of perinatal care from August 16, 2018 [Rozporządzenie Ministra Zdrowia z dnia 16 sierpnia $2018 \mathrm{r}$. w sprawie standardu organizacyjnego opieki okołoporodowej.] http://prawo.sejm.gov.pl/isap.nsf/download. xsp/WDU20180001756/O/D20181756.pdf [access: September 26, 2019, at $8: 16$ p.m.].

4. Gaviria SL, Dugue M, Vergel J, Restrepo D. Perinatal depressive symptoms: prevalence and associate psychosocial factors. Rev Colomb Psiquiatr. 2019; 48(3): 166-173. https://doi.org/10.1016/j.rcp.2017.09.002 5. Mukherjee S, Fennie K, Coxe S, Madhivanan P, Trepka MJ. Racial and ethnic differences in the relationship between antenatal stressful life events and postpartum depression among women in the United States: does provider communication on perinatal depression minimize the 
risk? Ethn Health 2018; 23(5): 542-565. https://doi.org/10.1080/13557 858.2017.1280137

6. Mbarak B, Kilewo Ch, Kuganda S, Sunguya BF. Postpartum depression among women with pre-eclampsia and eclampsia in Tanzania; a call for integrative intervention. BMC Pregnancy Childbirth 2019; 19: 27. https://dx.doi.org/10.1186\%2Fs12884-019-2395-3

7. Rogathi JJ, Manongi R, Mushi D, Rasch V, Sigalla GN, Gammeltoft $T$, et al. Postpartum depression among women who have experienced intimate partner violence: A prospective cohort study at Moshi, Tanzania. J Affect Disord.2017; 218: 238-245. https://doi.org/10.1016/j. jad.2017.04.063

8. Mahenge B, Stöckl H, Mizinduko M, Mazalale J, Jahn A. Adverse childhood experiences and intimate partner violence during pregnancy and their association to postpartum depression. J Affect Disord. 2018; 229: 159-163. https://doi.org/10.1016/j.jad.2017.12.036

9. Shiping L, Yan Y, Xiao G, Shiting X, Tingting S, Guangyu Z, et al. Risk factors for postpartum depression among Chinese women: path model analysis. BMC Pregnancy Childbirth 2017; 17: 133. https://dx.doi. org/10.1186\%2Fs12884-017-1320-x

10. Qandil S, Jabr S, Wagler S, Collin SM. Postpartum depression in the Occupied Palestinian Territory: a longitudinal study in Bethlehem. BMC Pregnancy Childbirth. 2016; 16(1): 375. https://doi.org/10.1186/ s12884-016-1155-x

11. Maeda Y, Ogawa K, Morisaki N, Tachibano Y, Horikawa R, Sago H. Association between perinatal anemia and postpartum depression: A prospective cohort study of Japanese women. Int J Gynaecol Obstet.2019 [Epub ahead of print] https://doi.org/10.1002/ijgo.12982

12. Alharbi AA, Abdulghani HM. Risk factors associated with postpartum depression in the Saudi population. Neuropsychiatr Dis Treat.2014; 10: 311-316. https://doi.org/10.2147/NDT.S57556

13. Roomruangwong C, Withayavanitchai S, Maes M. Antenatal and postnatal risk factors of postpartum depression symptoms in Thai women: A case-control study. Sex Reprod Healthc. 2016; 10: 25-31. https://doi. org/10.1016/j.srhc.2016.03.001

14. Yang F, Gardner CO Jr, Bigdeli T, Gao J, Zhang Z, Tao M, et al. Clinical features of and risk factors for major depression with history of postpartum episodes in Han Chinese women: A retrospective study. J Affect Disord. 2015; 183: 339-346. https://doi.org/10.1016/j.jad.2015.05.033

15. Cox JL, Holden JM, Sagovsky R. Detection of postnatal depression. Development of the 10-item Edinburgh Postnatal Depression Scale. Br J Psychiatry 1987; 150: 782-786. https://doi.org/10.1192/bjp.150.6.782

16. Kaźmierczak M, Gebuza G, Banaś P, Mieczkowska E, Gierszewska M. An evaluation of an exacerbation of postpartum depression in women up to one year after childbirth. Arch Perinat Med. 2017; 23(4): 198-206. https://www.researchgate.net/publication/325742832_An_evaluation_of_an_exacerbation_of_postpartum_depression_in_women_up_ to_one_year_after_childbirth

17. Hahn-Holbrook J, Cornwell-Hinrichs T, Anaya I. Economic and health predictors of national postpartum depression prevalence: a systematic review, meta-analysis, and meta-regression of $291 \mathrm{stu}-$ dies from 56 countries. Front Psychiatry 2017; 8: 248. https://dx.doi. org/10.3389\%2Ffpsyt.2017.00248 [PMC free article] [PubMed] [CrossRef] [Google Scholar]

18. Upadhyay RP, Chowdhury R, Salehi A, Sarkar K, Singh SK, Sinha B, et al. Postpartum depression in India: a systematic review and metaanalysis. Bull World Health Organ. 2017; 95(10): 706-717. https://dx.doi. org/10.2471\%2FBLT.17.192237

19. Özcan NK, Boyacioĝlu NE, Dinç H. Postpartum depression prevalence and risk factors in Turkey: A systematic review and meta-analysis. Arch Psychiatr Nurs. 2017; 31(4): 420-428. https://doi.org/10.1016/j. apnu.2017.04.006

20. Warzecha D, Gajda S, Kosińska-Kaczyńska K, Szymusik I, Wielgoś M. Risk factors for depressive symptoms in early postpartum period and after puerperium - are they the same? Neuro Endocrinol Lett.2016; 37(6): 452-460.

21. Silva RS, Junior RA, Sampaio VS, Rodrigues KO, Fronza M. Postpartum depression: a case-control study. J Matern Fetal Neonatal Med. 2019 https://doi.org/10.1080/14767058.2019.1671335 [Epub ahead of print]

22. Amirchaghmaghi E, Malekzadeh F, Chehrazi M, Ezabadi Z, Sabeti SH. A comparison of postpartum depression in mothers conceived by assisted reproductive technology and those naturally conceived. Int J Fertil Steril. 2020; 13(4): 277-281. https://doi.org/10.22074/ijfs.2020.5466 [Epub 2019 Nov 11.].

23. Tani F, Castagna V. Maternal social support, quality of birth experience, and post-partum depression in primiparous women. J Matern Fetal Neonatal Med. 2017; 30(6): 689-692. https://doi.org/10.1080/14 767058.2016.1182980

24. Abadiga M. Magnitude and associated factors of postpartum depression among women in Nekemte town, East Wollega zone, west Ethiopia, 2019: A community-based study. PLoS One. 2019; 14(11). https://doi. org/10.1371/journal.pone.0224792

25. Xiong R, Deng A. Incidence and risk factors associated with postpartum depression among women of advanced maternal age from Guangzhou, China. Perspect Psychiatr Care 2019. https://doi.org/10.1111/ppc.12430 [Epub ahead of print].

26. Smorti M, Ponti L. A comprehensive analysis of post-partum depression risk factors: the role of socio-demographic, individual, relational, and delivery characteristics. Front Public Health 2019. https://doi. org/10.3389/fpubh.2019.00295

27. Sylvén SM, Thomopoulos TP, Kollia N, Jonssson M, Skalkidou A. Correlates of postpartum depression in first time mothers without previous psychiatric contact. Eur Psychiatry. 2017; 40: 4-12. https:// doi.org/10.1016/j.eurpsy.2016.07.003

28. Chiu HC, Wang HY, Hsiao JC, Tzeng IS, Yiang GT, Wu MY, et al. Early breastfeeding is associated with low risk of postpartum depression in Taiwanese women. J Obstet Gynaecol. 2019 https://doi.org/10.1080/01 443615.2019.1603216 [Epub ahead of print]

29. Yim IS, Tanner Stapleton LR, Guardino ChM, Hahn-Holbrook J, Dunkel Schetter Ch. Biological and psychosocial predictors of postpartum depression: systematic review and call for integration. Annu Rev Clin Psychol. 2015; 11: 99-137. https://dx.doi.org/10.1146\%2Fannurev-clinpsy-101414-020426

30. Saxbe D, Rossin-Slater M, Goldenberg D. The transition to parenthood as a critical window for adult health. Am Psychol. 2018; 73(9): 1190-1200. https://doi.org/10.1037/amp0000376

31. Koszewska I. About depression during pregnancy and after childbirth. [O depresji w ciąży i po porodzie.] Wydawnictwo Lekarskie PZWL, Warszawa 2010.

32. Coates R, Ayers S, de Visser R. Women $>$ sexperiences of postnatal distress: a qualitative study. BMC Pregnancy Childbirth 2014; 14: 359. https://doi.org/10.1186/1471-2393-14-359

33. Maliszewska K, Bidzan M, Świątkowska-Freund M, Preis K. Medical and psychosocial determinants of risk of postpartum depression: a crosssectional study. Acta Neuropsychiatr. 2017; 29(6): 347-355. https://doi. org/10.1017/neu.2017.4

34. Maliszewska K, Bidzan M, Świątkowska-Freund M, Preis K. Relationship, social support, and personality as psychosocial determinants of the risk for postpartum blues. Ginekol Pol. 2016; 87(6): 442-447. https:// doi.org/10.5603/GP.2016.0023

35. Ongeri L, Wanga V, Otieno P, Mbui J, Juma E, Stoep AV, et al. Demographic, psychosocial and clinical factors associated with postpartum depression in Kenyan women. BMC Psychiatry 2018; 18: 318. https:// doi.org/10.1186/s12888-018-1904-7

36. Heim C, Newport DJ, Heit S, Graham YP, Wicox M, Bonsall R, et al. Pituitary-adrenal and autonomic responses to stress in women after sexual and physical abuse in childhood. JAMA 2000; 284(5): 592-597. https://doi.org/10.1001/jama.284.5.592 